Gut, 1982, 23, 603-607

\title{
Anti-LSP antibodies in acute liver disease
}

\author{
R MELICONI, A PERPERAS, D JENSEN, A ALBERTI, I G McFARLANE, \\ A L W F EDDLESTON, and ROGER WILLIAMS
}

From the Liver Unit, King's College Hospital and Medical School, London

SUMmaRY Sera from 71 patients with acute liver injury have been tested for antibodies to hepatocyte membrane lipoprotein complex (LSP) using a sensitive radioimmunoassay. Two main patterns of anti-LSP response were seen. In the first, seen in patients with type A and B viral hepatitis, anti-LSP antibodies were detectable at presentation, with the highest titres two to 10 days before the peak in serum aminotransferases and, in the hepatitis $B$ patients, when viral DNA polymerase concentrations were still high, indicating active viral replication. These findings are consistent with the anti-LSP response being consequent on an interaction between $T$ cells and neoantigens on the liver cell surface. A similar pattern was found in halothane hepatitis where immune responses to a halothane-altered liver membrane antigen are present early in the course of the disease. In the second type of response, exemplified by cases with paracetamol-induced hepatic necrosis, anti-LSP was only occasionally detectable at presentation, although present in very low titre later in the clinical course. This may be due to the release of altered antigen at the time of hepatocellular injury. The same pattern was found in a selected group of patients with uncomplicated acute alcoholic hepatitis, suggesting that in both these groups of patients the liver damage may have been due to a direct toxic effect on liver cells.

Autoantibodies which react with a hepatocyte membrane lipoprotein complex (LSP) have been detected in sera from almost all patients with untreated chronic active hepatitis and it has been suggested that these may be involved in the production of the periportal hepatocyte necrosis characteristic of this condition. ${ }^{1}$ A transient anti-LSP response is also a feature of acute virus hepatitis, ${ }^{1}$ a finding consistent with the hypothesis of Eddleston and Williams ${ }^{2}$ that the proliferation of autoreactive $B$ cells is triggered by the helper effect of $T$ cells directed against virus-coded antigens or altered self antigens on liver cells. Implicit in this concept is the view that the autoimmune anti-LSP response is not simply a secondary consequence of liver damage. If so, it should not be detectable in diseases in which the liver damage is due to direct toxic injury and where new membrane antigens are not found, a prediction which has been tested in the present study. Using a sensitive radioimmunoassay, ${ }^{3}$ antiLSP levels have been determined at the time of presentation in sera from 71 patients with acute viral or drug-induced liver injury. Serial measurements were also carried out to determine the timing of the

Received for publication 13 November 1981 antibody response in relation to the onset of liver damage and markers of viral replication.

\section{Methods}

PATIENTS

Sera were obtained from 71 patients within the first week after presentation with a hepatitic illness. Thirty-eight had an acute viral hepatitis, due to virus A infection in five (IgM antibody to hepatitis A detectable at presentation), virus $B$ infection in 22 (HBsAg-positive at presentation and becoming HBsAg-negative during recovery), and non- $A$, non$B$ virus infection in 11 (all with post-transfusion hepatitis and negative for HBsAg and IgM antiHAV). In 16 cases, fulminant liver failure had followed an overdose of paracetamol taken with suicidal intent and, in eight, massive liver cell necrosis was associated with multiple halothane anaesthesia. The remaining nine patients had histological evidence of acute alcoholic hepatitis with neutrophil infiltration, steatosis, and hyaline inclusions, but no underlying cirrhosis.

HBsAg, anti-HBs, and anti-HBc were determined by solid-phase radioimmunoassay (Ausria II, Ausab and Corab respectively). The determination 
of IgM anti-HAV was kindly performed by Professor A J Zuckerman and colleagues at the London School of Hygiene and Tropical Medicine by enzyme-linked immunosorbent assay (Organon Teknika). Dane-particle-associated DNA polymerase activity was measured according to the method of Kaplan et al. ${ }^{4}$

\section{RADIOIMMUNOASSAY FOR ANTI-LSP}

This is described in detail elsewhere. ${ }^{3}$ Serially diluted serum samples were incubated in duplicate with ${ }^{125}$ I-LSP $(25 \mu$ l serum with $2.5 \mathrm{ng}$ LSP) for three hours at $4^{\circ} \mathrm{C}$. Dried staphylococcal cells containing protein A (Sigma, London) were added to each tube (1 mg in $100 \mu$ l borate/Edta buffer) to facilitate precipitation of LSP/anti-LSP immune complex. The volume was then made up to $1 \mathrm{ml}$ with borate EDTA/albumin buffer and after centrifugation $0.5 \mathrm{ml}$ of the supernatant was removed. This and the remainder of the supernatant, including the pellet, was then counted in a $\gamma$-counter.

The percentage LSP binding was determined as follows:

$$
\frac{\text { cpm remainder }- \text { cpm upper } 0.5 \mathrm{ml}}{\text { cpm remainder }+ \text { cpm upper } 0.5 \mathrm{ml}} \times 100
$$

The mean percentage binding for each pair of samples was plotted on semilog graph paper against the reciprocal of serum dilution. The titre of anti-LSP of each serum sample was defined as the point of intersection between the line which linked the mean percentage binding values at the different dilutions with the upper limit of the normal range $($ mean $+3 \mathrm{SD})$, obtained in 20 normal controls.

\section{STATISTICAL METHODS}

The incidence of anti-LSP antibodies in the different disease groups was compared using the $\chi^{2}$ test with Yates's correction for small numbers. Titres of anti-LSP were compared using the non-parametric Wilcoxon rank sum test.

\section{Results}

In patients with acute viral hepatitis, anti-LSP was found in sera examined at the time of presentation in $100 \%$ and $86 \%$ respectively of those with type $\mathrm{A}$ and $B$. In non-A, non-B infection the incidence of anti-LSP $(27 \%)$ was significantly lower $(\mathrm{p}<0.05$ vs hepatitis $\mathrm{A}$ and $\mathrm{p}<0.005$ vs hepatitis $\mathrm{B}$ ). There were, however, no significant differences in titre in those positive for anti-LSP in the three groups (Fig. 1). Serial studies of the anti-LSP response in relation to changes in the pattern of viral replication and onset of liver damage in four patients with acute type B hepatitis who presented early in the source of

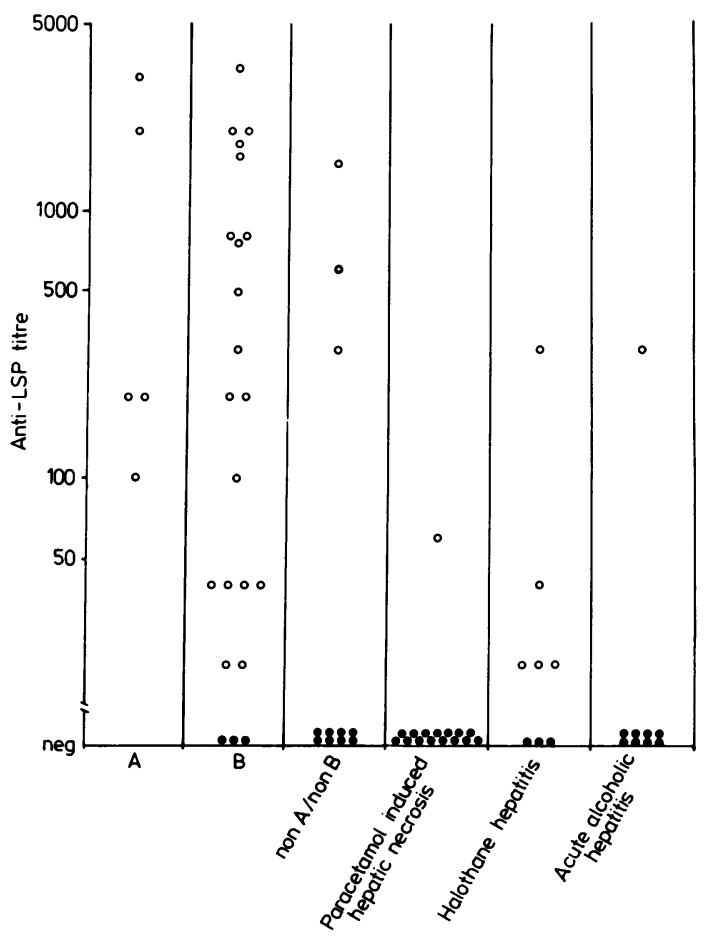

Fig. 1 Anti-LSP titres in serum from the 71 patients with acute liver damage grouped according to the aetiology of the liver cell injury. $\bigcirc$ Anti-LSP positive. $\bullet$ Anti-LSP negative.

the disease showed that the peak autoimmune response occurred before the time of maximum liver injury. The highest anti-LSP titres (ranging from $1: 200$ to $1: 3000$ ) were recorded from two to 10 days before the peak in the serum aspartate aminotransferase levels at a time when DNA polymerase levels were also at their highest (Fig. 2) indicating active viral replication. In acute type $A$ hepatitis the first serum sample obtained always had the highest serum aspartate aminotransferase and anti-LSP levels.

In contrast, only one $(6 \%)$ of the 16 patients with paracetamol-induced hepatic necrosis had detectable anti-LSP in serum at presentation, a frequency significantly lower than that found in hepatitis $A$ and $B(p<0.001)$. The anti-LSP titre was also low $(1: 60)$ in the one positive case. To investigate the possibility that an anti-LSP response might occur later in the course of the liver damage, serum samples were obtained from eight patients who survived two weeks or more (Fig. 3). The peak anti-LSP response was in the second week of illness at a time when serum aminotransferases were falling, the antibody 

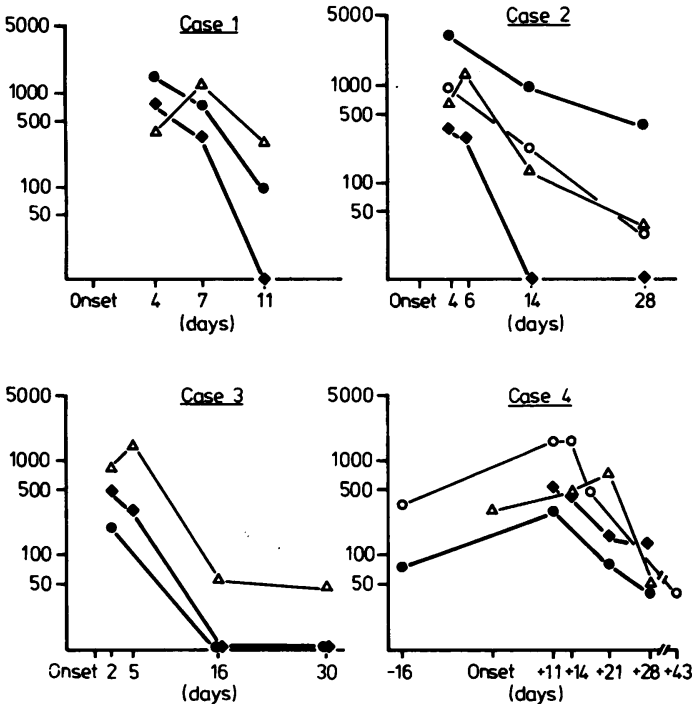

Fig. 2 Serial studies in four patients with acute hepatitis $B$ showing the relationship between serum levels of anti-LSP, hepatitis B surface antigen $(\mathrm{HBs} A \mathrm{~g}$ ) (reciprocal of the titres), virus-associated DNA polymerase (DNAP) $\left({ }^{3} \mathrm{H}\right.$ cpm), and aspartate aminotransferase (AST) (IU/l). - Anti-LSP. DNAP. $\triangle A S T$. ○ HBsAg.
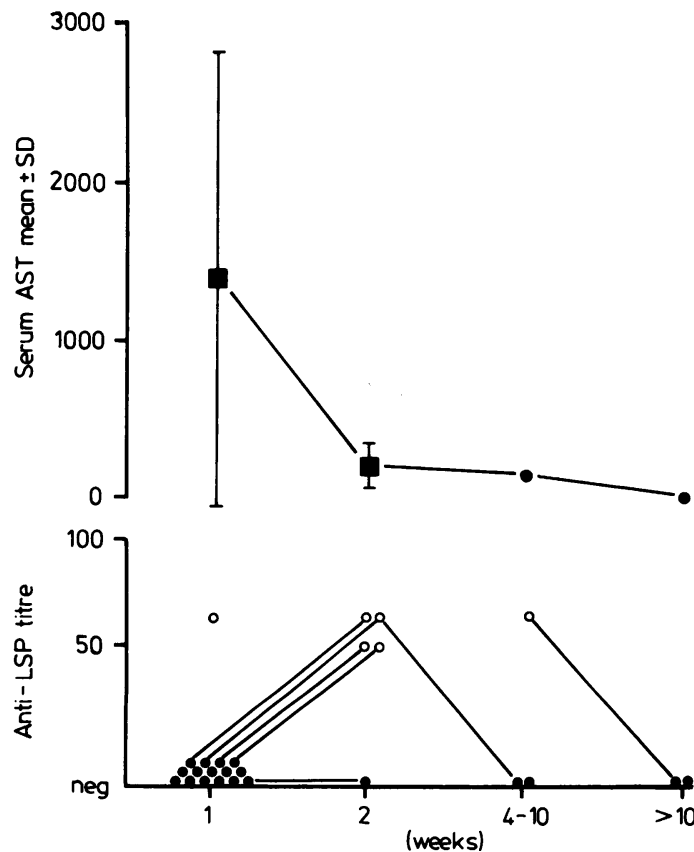

Fig. 3 Serial studies in patients with paracetamol-induced fulminant hepatic failure showing anti-LSP titre in serum and the mean of the serum aspartate aminotransferase (AST) values at the indicated times after presentation. being detected in four out of five cases studied at this time.

The titres were low $(1: 50$ to $1: 60)$ in all those patients and were significantly lower than those found in patients with acute viral hepatitis $(\mathrm{p}<0.01)$.

The findings in patients with acute alcoholic hepatitis were similar to those with paracetamolinduced liver damage, only one (11\%) having detectable anti-LSP antibodies in low titre in serum (Fig. 1). The frequency was higher in those with halothane-associated hepatitis (five $(63 \%)$ of the eight cases studied), but the titre of anti-LSP was, with one exception, low $(<1: 50)$.

\section{Discussion}

The early high titre anti-LSP response in types $\mathrm{A}$ and $B$ viral hepatitis is consistent with the concept that loss of tolerance is due to the helper effect of $T$ cells reacting with viral antigens on the surface of infected hepatocytes, ${ }^{2}$ although a virus-induced change in immunoregulation cannot be excluded. The close relationship in time between anti-LSP and DNA polymerase levels found in the serial studies in hepatitis B suggests a link between viral replication and the autoimmune response. Little is known of the effect of viral replication on the structure of the hepatocyte membrane, although immunofluorescent studies have shown the presence of HBsAg on the surface of liver cells isolated from liver biopsy specimens taken early in the course of acute type-B hepatitis. ${ }^{5} \mathrm{~T}$ cells which react with $\mathrm{HBsAg}$ have been detected in peripheral blood at this time by the techniques of leucocyte migration inhibition, ${ }^{6}$ lymphocyte transformation, ${ }^{7}$ and cytotoxicity. ${ }^{89}$ The large amounts of $\mathrm{HBsAg}$ in the circulation and HBsAg/anti-HBs immune complexes ${ }^{10}$ may, however, interfere with the activity of these lymphocytes and it is possible that other viral antigens also appear on the surface of infected cells ${ }^{11}$ and could be more important antigens for both cytotoxic and helper $\mathrm{T}$ cells.

Interpretation of the findings in patients with non- $A$, non-B hepatitis is complicated by the absence of viral markers, making it difficult to determine the stage of the illness in relation to viral replication and liver damage. A further complication is the recognition of two main subgroups differing in their incubation periods, ${ }^{12}{ }^{13}$ and until serological tests become available, it will not be possible to determine whether the heterogeneity of the anti-LSP response reflects differences in the immunopathology of these two varieties of the disease, variations in the immune response of different individuals or in the time of presentation in relation to the course of the illness. 
The finding of an anti-LSP response in halothane hepatitis, although titres were lower than in viral hepatitis, is in accord with the recent studies which have suggested that the immunopathology in these patients may be very similar to that in virus infection. Most patients with halothane-associated fulminant hepatic failure have antibodies in the serum which react with a neoantigen on the surface of hepatocytes isolated from halothaneanaesthetised rabbits. ${ }^{14}$ Formation of this neoantigen is associated with the metabolic degradation of halothane via an oxidative pathway. ${ }^{15}$ This could be the stimulus for a T-cell response which, through a helper effect, could also activate anti-LSP antibody formation. Direct lymphocyte cytotoxicity studies have confirmed such a dual response in these patients directed against both halothane-altered and LSP determinants. ${ }^{16}$

A quite different pattern of response was observed in the patients with paracetamol-induced hepatic necrosis, anti-LSP being rarely detectable at presentation and found only in low titre later in the course of the illness. The liver damage after paracetamol overdose is due to the production of reactive metabolites of the drug which bind to microsomal proteins and disrupt normal cellular metabolism. ${ }^{17}$ Using techniques similar to those developed to detect the halothane-altered liver membrane determinants described above we have been unable to demonstrate immune responses to paracetamol-altered liver cells. ${ }^{14}$ In the absence of membrane alterations, $T$ helper cells would not be activated and early loss of tolerance would not occur. Altered liver antigens, however, might be released at the time of hepatocyte necrosis and it is possible that these were responsible for the later, low-titre anti-LSP response that was observed.

The findings in acute alcoholic hepatitis were similar to those in patients with paracetamolinduced liver damage and suggest that alcohol or a metabolite was acting as a direct chemical hepatotoxin. However, these cases were all selected as examples of an uncomplicated acute hepatitic reaction and, in a larger series of patients with various types of alcohol-related liver damage, anti-LSP antibodies have been detected in several cases with cirrhosis and the histological features of portal lymphocytic infiltration and periportal hepatocyte necrosis similar to that seen in chronic active hepatitis. ${ }^{18}$ It is possible that the wide variation in the histological response to alcohol reflects the balance between direct alcohol toxicity on the one hand and immune responses induced by alcoholaltered liver antigens on the other.

It is not clear whether the autoimmune response to LSP described here in some patients with acute hepatitis contributes to liver damage in vivo, although it is clear that it does not always follow liver injury. Liver biopsy was not indicated in the majority of patients and a comparison of the histological pattern of liver damage between those with and those without anti-LSP is therefore not possible. The anti-LSP antibodies detected by the radioimmunoassay used here are almost certainly unrelated to 'liver membrane antibodies' described in some cases of acute and chronic active hepatitis ${ }^{19}$ and detected by immonufluorescence as antibodies that will bind to isolated rabbit hepatocytes. The antigenic determinants with which the majority of this liver membrane antibody reacts ( $\mathrm{LMAg}$ ) are not found in the type of LSP preparation used in the present study. ${ }^{20}$

We are indebted to the Wellcome Trust for their support and to Professor A J Zuckerman for the IgM-anti HAV tests.

\section{References}

1 Jensen DM, McFarlane IG, Portman BS, Eddleston ALWF, Williams R. Detection of antibodies directed against a liver-specific membrane lipoprotein in patients with acute and chronic active hepatitis. $N$ Engl J Med 1978; 299: 1-7.

2 Eddleston ALWF, Williams R. Inadequate antibody response to HBAg or suppressor T-cell defect in development of active chronic hepatitis. Lancet 1974; 2: $1543-5$.

3 Jensen DM, McFarlane IG, Nicholson A, Eddleston ALWF, Williams $R$. The development of a radioimmunoassay for the detection of antibodies to a liver-specific membrane lipoprotein (LSP). J Clin Lab Immunol 1978; 1: 1-7.

4 Kaplan PM, Greenman RL, Gerin JL, Purcell RH, Robinson WS. DNA polymerase associated with human hepatitis B. J Virol 1973; 12: 995-1005.

5 Alberti A, Realdi G, Tremolada F, Spina GP. Liver cell surface localisation of hepatitis $B$ antigen and of immunoglobulins in acute and chronic hepatitis and in liver cirrhosis. Clin Exp Immunol 1976; 25: 396-402.

6 De Moura MC, Vernace SJ, Paronetto F. Cellmediated immune reactivity to hepatitis B surface antigen in liver diseases. Gastroenterology 1975; 67: 310-7.

7 Tong MJ, Wallace AM, Peters RL, Reynolds TB. Lymphocyte stimulation in hepatitis B infections. $N$ Engl J Med 1975; 283: 318-22.

8 Alberti A, Realdi G, Bortolotti F, Rigoli AM. T lymphocyte cytotoxicity to HBsAg-coated target cells in hepatitis B virus infection. Gut 1977; 18: 1004-9.

9 El Sheikh N, Osman, CA, Cullen SH, Eddleston 
ALWF, Williams R. T lymphocyte-mediated cytotoxicity in HBsAg-positive liver disease. Clin Exp Immunol 1978; 31: 150-7.

10 Mandalinski K, Bqagiel I. HBsAg immune complexes in the course of infection with hepatitis B virus. Clin Exp Immunol 1979; 36: 371-8.

11 Gudat F, Bianchi L. Evidence for phasic sequences in nuclear HBsAg formation and cell membrane directed flow of core particles in chronic hepatitis B. Gastroenterology 1977; 73: 1194-7.

12 Mosley JW, Redecker AG, Feinstone SM, Purcell RH. Multiple hepatitis viruses in multiple attacks of acute viral hepatitis. N Engl J Med 1977; 296: 75-8.

13 Shirachi R, Shiraishi H, Tateda A, Kikuchi K, Ishada $N$. Hepatitis ' $c$ ' antigen in non-A, non-B posttransfusion hepatitis. Lancet 1978; 2: 853-6.

14 Vergani D, Mieli-Vergani G, Alberti A, Neuberger J, Eddleston ALWF; Davis M, Williams R. Antibodies to the surface of halothane-altered rabbit hepatocytes in patients with severe halothane-associated hepatitis. $N$ Engl J Med 1980; 303: 66-71.

15 Neuberger JM, Mieli-Vergani G, Tredger M, Davis M, Williams R. Oxidative metabolism of halothane in the immunopathogenesis of the associated liver damage. (Abstract). Gut 1981; 22: 669-73.

16 Mieli-Vergani G, Vergani D, Tredger JM, Eddleston ALWF, Davis M, Williams R. Lymphocyte cytotoxicity to halothane-altered hepatocytes in patients with severe hepatic necrosis following halothane anaesthesia. J Clin Lab Immunol 1980; 4: 49-53.

17 Jollow DJ, Mitchell JR, Potter WZ, Davis DC, Gillette JR, Brodie BB. Acetaminophen-induced hepatic necrosis. II. Role of covalent binding in vivo. $J$ Pharmacol Exp Ther 1973; 187: 195-201.

18 Perperas A, Tsantoulas D, Portmann B, Eddleston ALWF, Williams R. Autoimmunity to liver membrane protein and liver damage in alcoholic liver disease. Gut 1981; 22: 149-53.

19 Tage-Jensen U, Arnold W, Dietrichson O et al. Liver cell membrane autoantibody specific for inflammatory liver disease. $\mathrm{Br}$ Med J 1977; 1: 206-9.

20 Meyer zum Buschenfelde KH, Manns, M, Hutteroth TH, Hopf U, Arnold W. LM-Ag and LSP - two different antigens involved in the immunopathogenesis of chronic active hepatitis. Clin Exp Immunol 1979; 37: 205-12. 